\title{
Extracellular matrix remodelling in COPD
}

\author{
Meropi Karakioulaki $\mathbb{1}^{1}$, Eleni Papakonstantinou ${ }^{1,2}$ and Daiana Stolz ${ }^{1}$
}

Affiliations: ${ }^{1}$ Clinic of Pulmonary Medicine and Respiratory Cell Research, University Hospital, Basel, Switzerland. 'Dept of Pharmacology, Faculty of Medicine, Aristotle University of Thessaloniki, Thessaloniki, Greece.

Correspondence: Daiana Stolz, Clinic of Pulmonary Medicine and Respiratory Cell Research, University Hospital Basel, Petersgraben 4, CH-4031 Basel, Switzerland. E-mail: daiana.stolzQusb.ch

@ERSpublications

Airway remodelling in COPD refers to alterations of the lung ECM that affect airway wall thickness, resistance and elasticity. Unravelling such molecular modifications will help us to identify novel biomarkers for disease progression and therapy. https://bit.ly/2LObAga

Cite this article as: Karakioulaki M, Papakonstantinou E, Stolz D. Extracellular matrix remodelling in COPD. Eur Respir Rev 2020; 29: 190124 [https://doi.org/10.1183/16000617.0124-2019].

ABSTRACT The extracellular matrix (ECM) of the lung plays several important roles in lung function, as it offers a low resistant pathway that allows the exchange of gases, provides compressive strength and elasticity that supports the fragile alveolar-capillary intersection, controls the binding of cells with growth factors and cell surface receptors and acts as a buffer against retention of water. COPD is a chronic inflammatory respiratory condition, characterised by various conditions that result in progressive airflow limitation. At any stage in the course of the disease, acute exacerbations of COPD may occur and lead to accelerated deterioration of pulmonary function. A key factor of COPD is airway remodelling, which refers to the serious alterations of the ECM affecting airway wall thickness, resistance and elasticity. Various studies have shown that serum biomarkers of ECM turnover are significantly associated with disease severity in patients with COPD and may serve as potential targets to control airway inflammation and remodelling in COPD. Unravelling the complete molecular composition of the ECM in the diseased lungs will help to identify novel biomarkers for disease progression and therapy.

\section{The extracellular matrix of the lung}

The tissue architecture of the lung is determined by the pulmonary extracellular matrix (ECM) that provides the mechanical stability and elasticity of the tissue. The ECM of the lung consists of cartilage, provisional matrix, basement membranes and interstitial matrix [1]. Proteoglycans (PGs), glycosaminoglycans (GAGs), collagens and elastin are the main molecules of the lung ECM, with a high turnover of $10 \%$ daily (figure 1a) [2]. The interstitial matrices form a fibril-like network that maintains the three-dimensional structure of the lung by interconnecting cells and tissues. The interstitial matrices contain collagens type I, III and VI and appears to be the area of the lung that is mainly affected by inflammation [8-12]. The basement membranes contain collagen type IV and glycoproteins and cover epithelia and endothelia [1].

The ECM of the lung forms a supportive framework into which the fragile lung structures are embedded. This framework provides elasticity and plays several important roles associated with lung function. The lung ECM also interacts with cell surface receptors and binds growth factors and, hence, controls cell behaviour. In addition, the lung ECM acts as a buffer against retention of water [13, 14]. During inflammation there is an active interaction between inflammatory cells and ECM molecules in the lung [15]. For example, it has been shown that the interaction of leukocytes with a number of different ECM components is a critical part of the inflammatory response as it impacts their phenotype [16].

Provenance: Submitted article, peer reviewed

Received: 23 Sept 2019 | Accepted after revision: 16 May 2020

Copyright $\odot$ ERS 2020. This article is open access and distributed under the terms of the Creative Commons Attribution Non-Commercial Licence 4.0. 


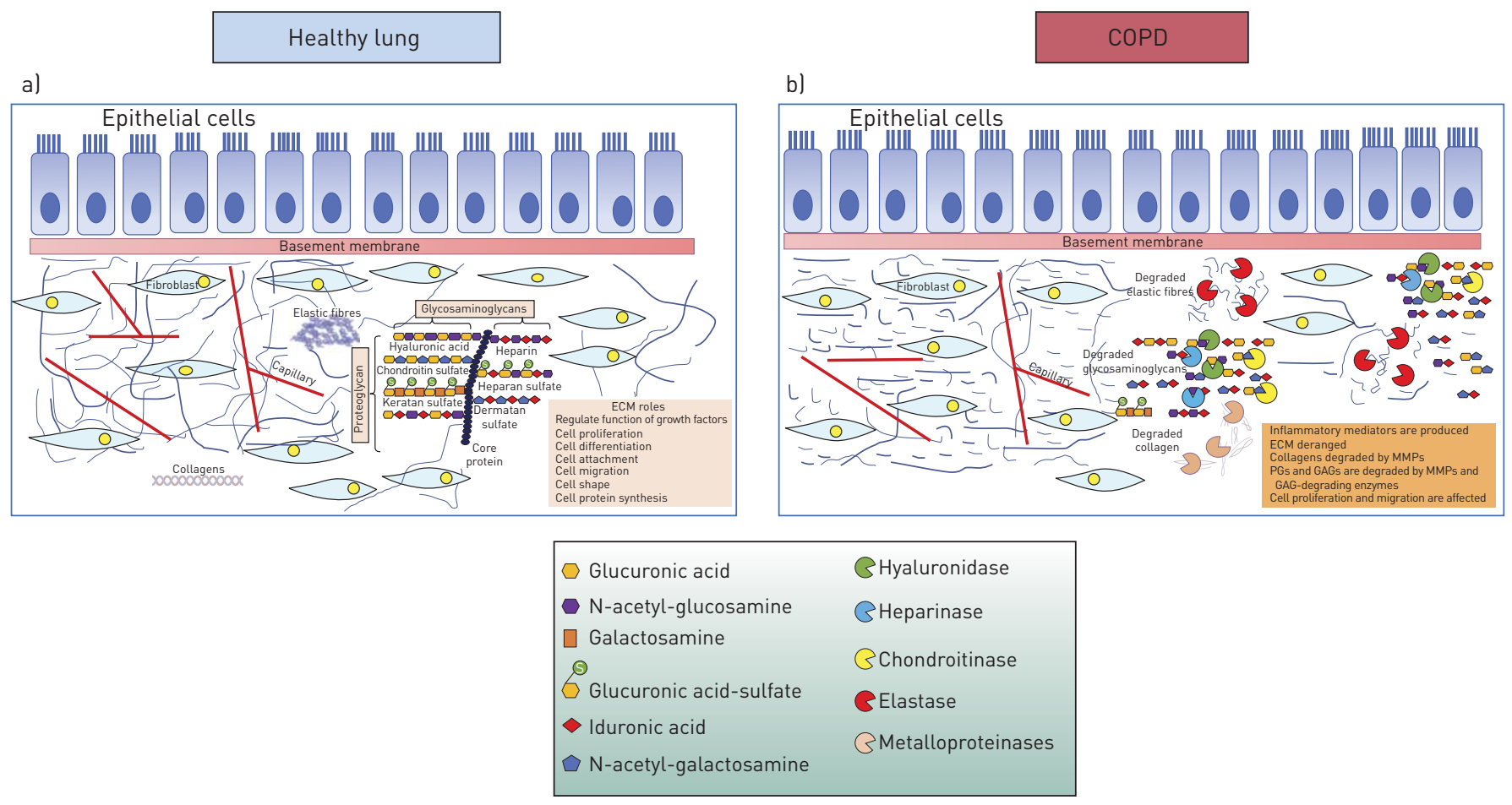

FIGURE 1 Extracellular matrix (ECM) modifications in COPD. a) In the healthy lung, intact ECM consists of elastic fibres, proteoglycans and collagens and regulates the function of growth factors, as well as cell proliferation, differentiation, attachment, migration, shape and protein synthesis. b) In COPD, ECM is degraded by ECM enzymes, such as elastase, hyaluronidases, chondroitinases and metalloproteinases, leading to the production of inflammatory mediators that affect cellular functions [2-7]. GAG: glycosaminoglycan; MMP: matrix metalloproteinase; PG: proteoglycan.

\section{ECM collagens and elastin of the lung}

Among other molecules, collagens constitute a predominant component of the lung ECM. Collagens that contribute to the lung architecture are fibrillar collagens types I, II, III, V and XI, characterised by high tensile strength and low elasticity $[17,18]$. Collagens type I and III together with elastin are the major components of the ECM of the alveoli $[19,20]$. Type IV collagen is involved in cell migration, proliferation, adhesion and differentiation [9]. Collagens I and V form the lamina reticularis [21, 22]; they are involved in lung shape maintenance in respiration and represent $15-20 \%$ of the dry weight of the lung.

Lung tissue elasticity is mainly attributed to elastic fibres that are characterised by high elasticity and low tensile strength. The inner core of elastic fibres consists of elastin and the outer layer contains microfibrils $[23,24]$. Elastin remodelling appears to be very low in healthy states; however, elastin remodelling levels are elevated in pulmonary diseases $[25,26]$. In pulmonary emphysema, elastin is the major target of decomposition leading to loss of lung elasticity [27]. In addition to elastin, collagen remodelling also contributes to structural changes associated with emphysema [28]. Collagen synthesis is triggered by elastase that degrades ECM molecules but also by transforming growth factor (TGF)- $\beta 1$ produced by macrophages $[29,30]$.

\section{ECM glycosaminoglycans and PGs of the lung}

PGs and GAGs also belong to the major constituents of the nonfibrillar compartment of the lung ECM [31]. GAGs are long, linear, sulfated polysaccharides consisting of repeating disaccharide units, with various compositions of the disaccharide unit and degree of sulfation (figure 1a). Depending on the number of the repeating dissacharide units, the molecular mass of GAGs may vary by over three orders of magnitude [32]. With the exception of hyaluronic acid, GAGs are usually covalently attached to a protein core forming PGs [33]. There are two main types of GAGs: the nonsulfated GAG hyaluronic acid (or hyaluronan) and the sulfated GAGs (heparan sulfate and heparin, chondroitin sulfate, dermatan sulfate and keratan sulfate) (figure 1a).

Hyaluronic acid is the most abundant GAG in the lung ECM. In contrast to other GAGs, which are secreted through the Golgi apparatus, hyaluronic acid is spun out from the cell membrane. Hyaluronic acid is composed of up to 10000 disaccharides and has a molecular mass of up to $\times 10^{7}$ Daltons. It has a high anion charge, and this unique characteristic of hyaluronic acid is important for some of its functions, 
as it can bind many water molecules and can offer hydration to tissues [34]. Hence, accumulation of hyaluronic acid in the interstitial tissue regulates the water content in the interstitium [35]. It is the only GAG not bound to a protein core and its biological functions depend on its molecular size [3]. High molecular weight hyaluronic acid exhibits anti-angiogenic, anti-inflammatory and immune-suppressive effects, while low molecular weight hyaluronic acid is pro-angiogenic and pro-inflammatory [36, 37]. Hyaluronic acid has been associated with normal lung homeostasis and pulmonary diseases [38]. Its synthesis and degradation are controlled by specific enzymes, the HA synthases and hyaluronidases, respectively $[39,40]$.

Hyaluronic acid binds to its cell surface receptor CD44 on cells and affects their phenotype [41]. It has been shown that lack of CD44 in bleomycin-treated animals leads to accumulation of hyaluronic acid in the lungs due to the inability of lung cells to clear hyaluronic acid via CD44 [42]. Excessive accumulation of hyaluronic acid results in accumulation of its fragments which interact with immune cells to promote the expression of specific inflammatory cytokines and chemokines that drive the immune response. It has been shown that low molecular weight hyaluronic acid activated the expression of inflammatory genes in epithelial cells, dendritic cells, endothelial cells, fibroblasts and macrophages $[43,44]$.

Heparan sulfate is very abundant in the parenchyma of the lung; it has a molecular mass ranging from 5$70 \times 10^{3}$ Daltons. Heparan sulfate interacts with various growth factors and cytokines such as interleukin (IL)-5, IL-6, IL-8, IL-10 and tumour necrosis factor (TNF)- $\alpha$ and platelet factor-4 [45-47] and modulates their function.

Heparin is an over-sulfated GAG with similar structure and function to heparan sulfate. The size of heparin ranges from $6-50 \times 10^{6}$ Daltons and is commonly used as an anticoagulant drug [48]. Synthesis of heparin takes place mainly in mast cells and, therefore, the lung is a rich source of heparin [49]. Mast cell heparin resides in secretory granules, where most of the GAG chains are linked to a core protein, forming macromolecular PGs that are much larger than commercial heparin.

Chondroitin sulfate regulates ECM protein degradation by activating ECM degrading enzymes such as matrix metalloproteinases (MMPs). For example, chondroitin sulfate is involved in the degradation of the chondroitin sulfate rich PG aggrecan by MMP-2 [50, 51], MMP-13 [52], ADAMTS4 [52] and ADAMTS7B [53]. MMP-2 is activated by direct binding of chondroitin sulfate to the C-domain of pro-MMP-2, which is essential to present the inactive enzyme to its activator, the membrane type $3 \mathrm{MMP}$ [50]. Previous studies have shown that chondroitin sulfate plays a dynamic role in embryonic lung growth and morphogenesis [54]. Furthermore, versican, a chondroitin sulfate PG, interacts with toll-like receptors on alveolar macrophages promoting the production of inflammatory cytokines [55-57].

Dermatan sulfate, among others, is involved in the adhesion of pneumococci to nasopharyngeal epithelial cells [58], of Penicillium marneffei to the ECM of the host [59], and of spirochetes to fibronectin [60]. Additionally, dermatan sulfate affects the function of growth factors in the lung and influences proliferation [61-63].

Keratan sulfate is found abundantly in airway secretions [64]; however, there are no available data for its function in the lung. Keratan sulfate is usually found attached to aggrecan, which is a large PG. It has been shown that there is an increase in the length and degree of sulfation of keratan sulfate with age $[65,66]$.

\section{COPD}

COPD is a chronic inflammatory respiratory condition that is mainly caused by smoke exposure. It is characterised by progressive airflow limitation which is not fully reversible [2] and caused by structural remodelling of the small airways that affects airway wall thickness, resistance and elasticity [67, 68]. Apart from small airway remodelling, airflow limitation can be caused by emphysema which is characterised by an enlargement of the respiratory air spaces in the alveoli [27].

Besides emphysema, persistent inflammation in COPD leads to disruption of normal repair and defines mechanisms resulting in small airway fibrosis. These structural changes culminate in loss of lung elasticity, entrapping of gas, and progressive airflow limitation [69]. Chronic inflammation in COPD is associated with increased numbers of fibroblasts in the airways, as well as inflammatory cells such as macrophages, neutrophils, CD4+ and CD8+ T-lymphocytes [70]. These cells secrete MMPs, such as MMP-1, MMP-8, MMP-13 and MMP-12, that degrade ECM molecules and result in the destruction and remodelling of the ECM in small airways [71] and in the parenchyma (figure 1b) [72].

In response to fibre destruction by MMPs, there is a structural reorganisation of parenchymal fibres, constituting a dynamic process of repair and remodelling [73]. This process involves changes in major lung ECM components, such as collagens I and III, and elastin, leading to the loss of elasticity, during emphysema progression $[74,75]$. 
Although emphysema is characterised by the destruction of distal air spaces, with or without fibrosis, the majority of clinical studies with patients at advanced stages have shown an increase in the amount of ECM fibre deposition in the airways and the lung parenchyma [76, 77].

Acute exacerbations of COPD (AECOPD) may occur at any time and lead to accelerated deterioration of pulmonary function [2], as the distribution of transpulmonary pressure is disturbed, resulting in hyperinflation [27]. Frequent exacerbations lead to a more rapid decline in lung function, and this affects exercise capacity, quality of life and survival in COPD patients [78]. Despite the fact that AECOPD may determine the progression of the disease, there is limited information concerning the means by which AECOPD events may result to structural changes, loss of elasticity and remodelling in lung tissue (table 1) [2].

Furthermore, both chronic inflammation in COPD and AECOPD are associated with altered homeostasis of the lung's ECM molecules (figure 1b) [67, 89].

\section{Alterations of ECM molecules in COPD}

Altered ECM turnover is a hallmark of several pulmonary diseases, including COPD, and underlines the importance of ECM homeostasis for proper lung function (table 1) [90-92]. In the lung, the ECM is subjected to a daily turnover of about $10 \%$ of total ECM, indicating that subtle changes in turnover rates accumulate over time to cause large changes in total ECM composition [93].

The majority of ECM studies in COPD patients have been restricted to samples from biopsies or lung resection. Experimental models have also been used to understand changes in ECM during COPD. The most commonly used animal models for COPD are the cigarette-induced and the elastase-induced models in rodents. Similarities and discrepancies in experimental data between human and animal models have been recently reviewed by ITO et al. [69]. Both animal models show an inflammatory process characterised mainly by increased macrophages as well as by neutrophils and CD4+ and CD8+ T-lymphocytes [94, 95]. As in humans, MMP-12 is the metalloprotease that along with TGF- $\beta$ is described in animal models of COPD to modulate increase in elastin and collagens $[94,96]$. It is worth mentioning that in animal models with COPD, lung function parameters do not reflect structural changes in the lung, mainly due to technical difficulties in performing lung function tests in small animals [97].

During the past few years, large cohort clinical trials, such as the PROMISE study [4] or the ECLIPSE study [98], focused on the identification of serum biomarkers that would enable the adequate assessment of airway inflammation in COPD. Such biomarkers would contribute to a more precise diagnosis of disease states in clinical practice and, furthermore, would lead to earlier diagnosis of exacerbations and more personalised interventions. However, the degree to which serum biomarkers reflect ongoing inflammatory processes within the lung is largely unknown and there are only a few studies that have addressed the issues of similarity and repeatability of systemic and pulmonary biomarkers [99-101]. In this respect, results from the ECLIPSE study showed that there is only a weak association between sputum neutrophils and four serum markers [100]. In another study comparing a large panel of biomarkers in bronchoalveolar lavage (BAL), bronchial biopsies, serum and induced sputum, the authors concluded that, while serum markers can discriminate between smokers with and without COPD, they do not seem to sufficiently reflect the disease-associated inflammatory processes within the airways. We have recently shown that pro-inflammatory degradation of hyaluronic acid in AECOPD can be comparably detected in serum samples as well as in BAL of COPD patients $[3,4]$.

\section{Elastic fibres and collagens}

Airflow obstruction and hyperinflation are the major pathophysiological aspects of COPD. The limitation of airflow is the result of small airway remodelling that leads to damage of small airways and emphysema [18]. As a result, the distribution of transpulmonary pressure is disrupted and the lungs are hyperinflated. Consequently, biomechanical changes occur and manifest as loss of lung elasticity. As elastin is the core component of elastic fibres, it is the major target of disintegration in the remodelling process. A widely accepted hypothesis for the development of emphysema is the imbalance of protease and antiprotease activity [80]. Studies using mouse disease models of emphysema have shown that intratracheal administration of elastase, the enzyme that degrades elastin, together with deficiency of the inhibitor of elastase, $\alpha 1$-antitrypsin, result in emphysema [80].

However, changes in lung biomechanics are not only the result of the destruction of elastic fibres. Collagen remodelling in the alveolar wall is also a key event contributing to structural and biomechanical changes found in emphysema [28]. ECM-degrading enzymes such as MMPs are major players in these processes. They are mainly secreted by inflammatory cells such as macrophages, neutrophils and T-cells and are involved in ECM degradation [12, 25, 26, 102, 103]. The expression of MMPs and their proteolytic activity are increased during tissue inflammation, resulting in fragments of ECM molecules that are released into 
TABLE 1 Alterations in extracellular matrix (ECM) molecules in COPD and pathological significance

\begin{tabular}{|c|c|c|c|c|}
\hline ECM component & $\begin{array}{l}\text { Main cell origin of the } \\
\text { ECM component }\end{array}$ & Physiological role in the lung & Alterations in COPD & Pathological significance \\
\hline Elastin & $\begin{array}{l}\text { Mesothelial cells in } \\
\text { the pleura, smooth } \\
\text { muscle cells in } \\
\text { airways and blood } \\
\text { vessels, endothelial } \\
\text { cells, interstitial } \\
\text { fibroblasts [79] }\end{array}$ & $\begin{array}{l}\text { The core component of elastic } \\
\text { fibres }\end{array}$ & $\begin{array}{l}\text { Major target of } \\
\text { disintegration in the lung } \\
\text { remodelling process }\end{array}$ & $\begin{array}{l}\text { Elastin remodelling levels } \\
\text { elevated in pulmonary } \\
\text { diseases }[25,26] \\
\text { Decomposition of elastin } \rightarrow \\
\text { development of emphysema } \\
\text { [80] }\end{array}$ \\
\hline Collagens & $\begin{array}{l}\text { Airway smooth muscle } \\
\text { cells, interstitial } \\
\text { fibroblasts, } \\
\text { epithelial cells [27] }\end{array}$ & $\begin{array}{l}\text { Collagen types I, III and VI are } \\
\text { the core components of the } \\
\text { interstitial matrix } \\
\text { Collagen type IV is the core } \\
\text { component of basement } \\
\text { membranes } \\
\text { Collagen types I and V allow } \\
\text { the lung to maintain its } \\
\text { shape during respiration } \\
\text { and form the lamina } \\
\text { reticularis [1] }\end{array}$ & $\begin{array}{l}\text { Collagen degradation is } \\
\text { up-regulated in COPD } \\
\text { [81, 82] } \\
\text { Serum fragments of } \\
\text { collagen types I, III, IV } \\
\text { and VI are associated } \\
\text { with disease severity } \\
\text { (airflow limitation, } \\
\text { dyspnoea) and outcome } \\
\text { (time to exacerbation and } \\
\text { prognosis) of COPD [2, 5] } \\
\text { Collagen type I degradation } \\
\text { is associated with } \\
\text { increased mortality in } \\
\text { COPD patients [83] }\end{array}$ & $\begin{array}{l}\text { Collagen remodelling in the } \\
\text { alveolar wall } \rightarrow \text { development } \\
\text { of emphysema [28] } \\
\text { Thickening of the lamina } \\
\text { reticularis leads to airway } \\
\text { limitation [8] }\end{array}$ \\
\hline \multicolumn{5}{|l|}{ Glycosaminoglycans } \\
\hline $\mathrm{HA}$ & $\begin{array}{l}\text { Airway smooth muscle } \\
\text { cells, interstitial } \\
\text { fibroblasts, } \\
\text { epithelial cells [27] }\end{array}$ & $\begin{array}{l}\text { Regulates water content in the } \\
\text { interstitium [35] } \\
\text { High molecular HA: } \\
\text { anti-angiogenic, } \\
\text { anti-inflammatory, } \\
\text { immune-suppressive } \\
\text { Low molecular HA: } \\
\text { pro-angiogenic, } \\
\text { pro-inflammatory }[36,37]\end{array}$ & $\begin{array}{l}\text { Decreased synthesis of HA } \\
\text { in airway smooth muscle } \\
\text { cells from COPD patients } \\
\text { [84] } \\
\text { Degradation of HA } \\
\text { contributes to } \\
\text { inflammation and decline } \\
\text { in lung function during } \\
\text { exacerbations of COPD [3] }\end{array}$ & $\begin{array}{l}\text { HA is a strong predictor of } \\
\text { overall survival in COPD [4] }\end{array}$ \\
\hline Heparin & $\begin{array}{l}\text { Mast cells, endothelial } \\
\text { cells [36] }\end{array}$ & $\begin{array}{l}\text { Synthesised by mast cells in } \\
\text { the lung [49] }\end{array}$ & & $\begin{array}{l}\text { Commonly used as } \\
\text { anticoagulant drug [48] }\end{array}$ \\
\hline $\begin{array}{l}\text { Chondroitin } \\
\text { sulfate }\end{array}$ & $\begin{array}{l}\text { Mast cells, airway } \\
\text { smooth muscle } \\
\text { cells, fibroblasts, } \\
\text { epithelial cells [87] }\end{array}$ & $\begin{array}{l}\text { Embryonic lung growth and } \\
\text { morphogenesis [54] }\end{array}$ & $\begin{array}{l}\text { Significantly increased in } \\
\text { the BAL of patients } \\
\text { during COPD } \\
\text { exacerbations [7] }\end{array}$ & $\begin{array}{l}\text { Associated with airway } \\
\text { remodelling } \rightarrow \text { leads to } \\
\text { obstruction rather than to } \\
\text { emphysema [7] }\end{array}$ \\
\hline Dermatan sulfate & $\begin{array}{l}\text { Fibroblasts, airway } \\
\text { smooth muscle } \\
\text { cells, epithelial } \\
\text { cells [64] }\end{array}$ & $\begin{array}{l}\text { Affects the function of growth } \\
\text { factors in the lung, } \\
\text { influences proliferation } \\
\text { [61-63] }\end{array}$ & & $\begin{array}{l}\text { Docking molecule for } \\
\text { microorganism [58] }\end{array}$ \\
\hline Keratan sulfate & $\begin{array}{l}\text { Bronchial epithelial } \\
\text { cells, epithelial } \\
\text { cells [88] }\end{array}$ & $\begin{array}{l}\text { Abundant in airway secretions } \\
\text { [64], no available data for its } \\
\text { function in the lung }\end{array}$ & & \\
\hline
\end{tabular}

HA: hyaluronic acid; HS: Heparan sulfate; IL: interleukin; TNF: tumour necrosis factor; BAL: bronchoalveolar lavage. 
the circulation [2]. Various studies have shown that in COPD, collagen degradation is upregulated [81, 82] and is associated with clinically relevant outcomes $[2,83,104]$. In COPD, not all lung compartments are affected the same way by abnormal collagen deposition. Electron micrographs have shown a high expression of elastin and collagen in the wall of alveoli in emphysema [76] but a lower expression of collagen I in the airways of COPD patients [105]. Comparison of ECM composition in various lung compartments between healthy controls and patients with COPD revealed alterations in elastic fibres, fibronectin, collagens, tenascin- $\mathrm{C}$ and versican throughout all lung compartments in samples with moderate COPD [105].

During AECOPD, turnover of ECM molecules is increased, leading to enzymatic degradation of ECM molecules such as elastin, collagens and PGs (figure 1b). These ECM fragments circulate in blood and have been proposed as potential biomarkers to predict COPD progression (figure 2) [83, 104]. In this respect, it has also been proposed that evaluation of degradation products of lung ECM proteins in blood can become a promising novel biomarker for the detection of COPD exacerbation [2]. In a multicentre, prospective, observational study of 506 COPD patients, serum biomarkers of ECM turnover were significantly associated with disease severity of COPD [2]. Specifically, patients with the lowest levels of the pro-forms of collagens type III and type VI had more severe airflow limitation, hyperinflation, air trapping and emphysema (figure 2a). Degradation products of collagens III and VI were associated with dyspnoea. In AECOPD, compared with stable state COPD, all biomarkers, except the pro-forms of collagen VI, were increased but no biomarkers, except neutrophil elastase-generated fragments of elastin, differed between the stable state and AECOPD follow-up (figure 3a). Additionally, the pro-form of collagen type III was associated with a shorter time to exacerbation and pro-form of collagen type VI was associated with a better survival rate (figure $2 \mathrm{~b}$ ) [2].

Moreover, compared with follow-up after AECOPD, degradation fragments of collagen types III, IV and VI have been shown to be increased during AECOPD; however, they were not associated with disease severity [82]. Degradation of collagen type I was associated with increased mortality in COPD patients [83, 104]. In a multicentre, prospective, observational study of 498 COPD patients [5], serum biomarkers of collagen remodelling were shown to be correlated with disease severity and outcome (figure $2 b$ ). Specifically, degradation fragments of collagens type I and type IV and the pro-forms of collagen type V,

a)

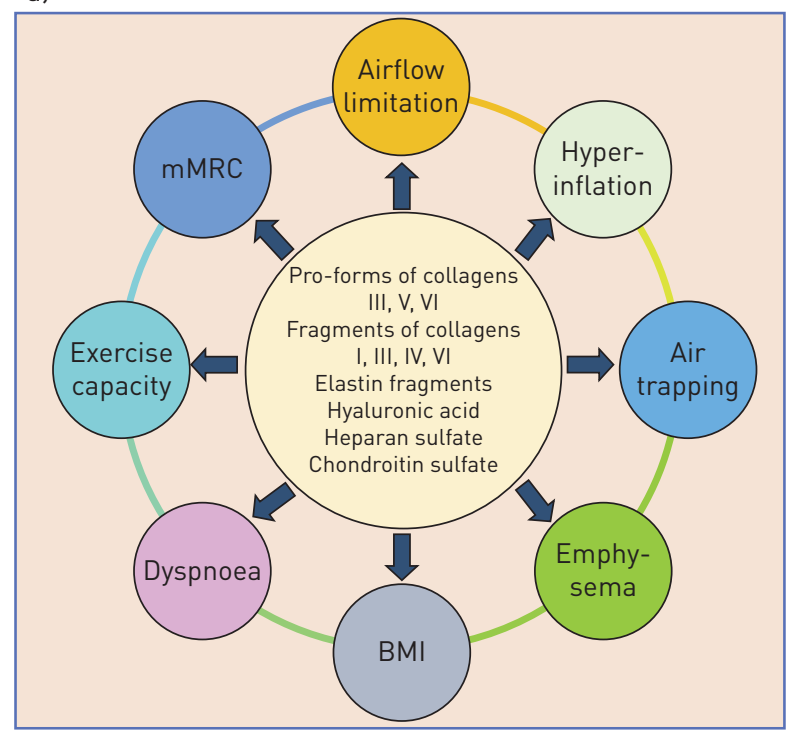

b)
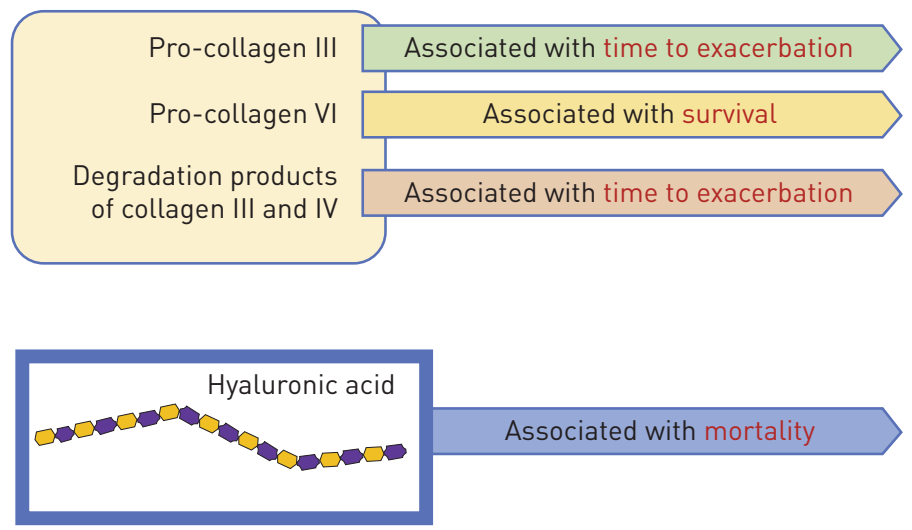

FIGURE 2 Turnover of extracellular matrix (ECM) molecules in COPD is associated with clinically relevant a) end-points and b) outcome. Serum

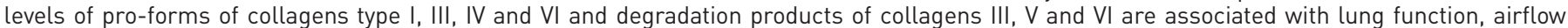

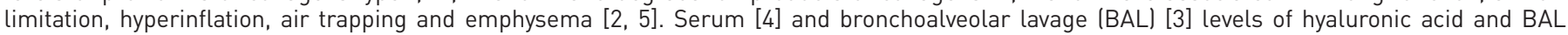

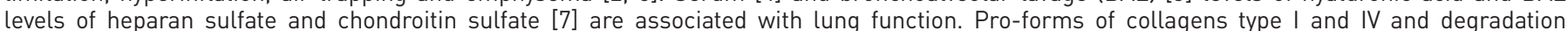
products of collagen type III were associated with time to exacerbation [2, 5] and hyaluronic acid was associated with mortality [4]. mMRC: modified Medical Research Council dyspnoea scale; BMI: body mass index. 


\section{Alterations in serum levels of ECM molecules at AECOPD}

a)

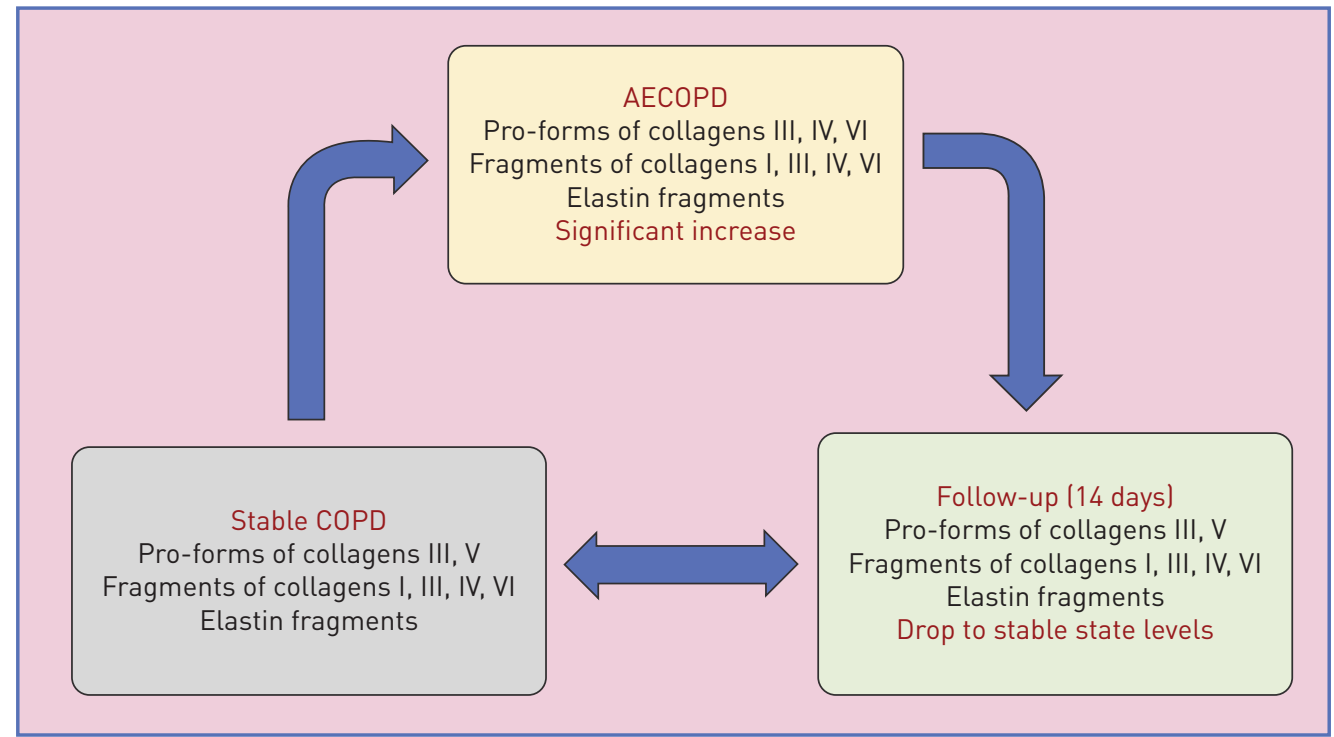

b)

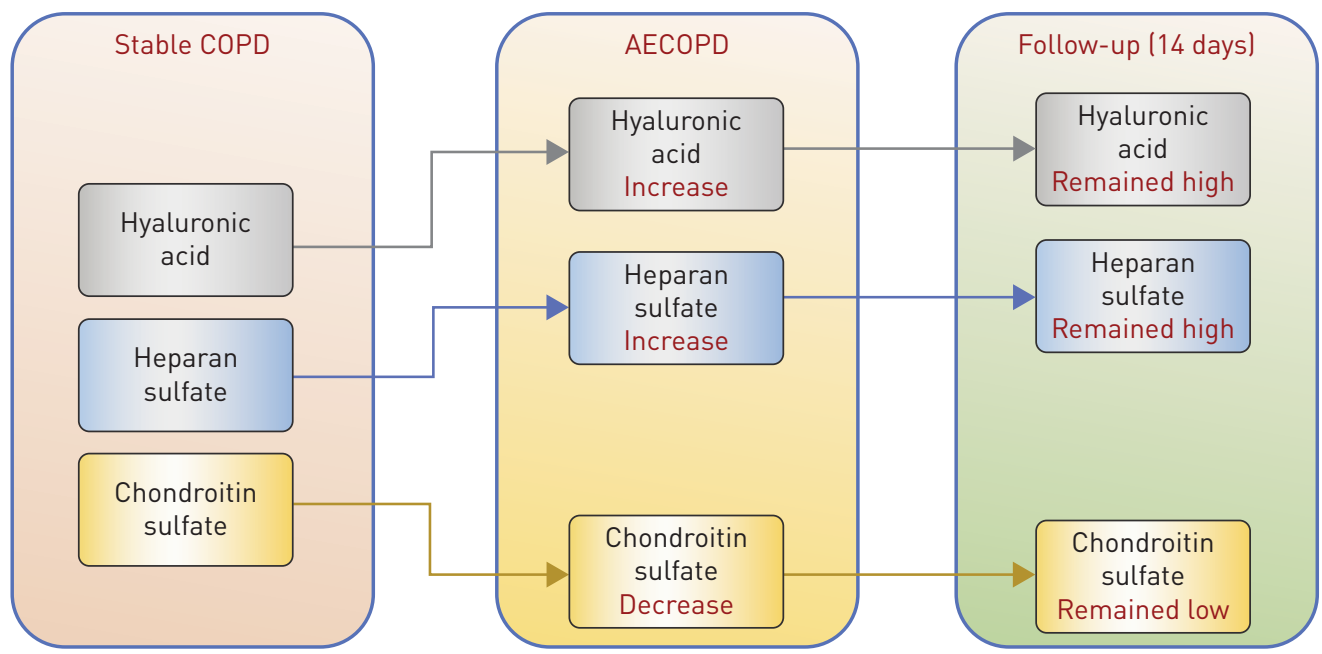

FIGURE 3 Serum levels of extracellular matrix (ECM) molecules are altered during acute exacerbations of COPD (AECOPD). a) Serum levels of collagen and elastin turnover products increase during AECOPD compared with stable COPD and drop to stable state levels at 14 days follow-up $[2,5]$. b) Serum levels of hyaluronic acid and heparan sulfate increase during AECOPD compared with stable COPD and remain at high levels at 14 days follow-up $[4,106]$. Serum levels of chondroitin sulfate decrease during AECOPD compared with stable COPD and remain at low levels at 14 days follow-up [106].

were increased in AECOPD compared with stable state and decreased in follow-up. Furthermore, all these biomarkers were higher at severe AECOPD compared with moderate AECOPD. Degradation fragments of collagens I, III and IV had a more significant influence on time to exacerbation. None of these biomarkers, however, appeared to be a good predictor of mortality in this study [5].

MMPs and their tissue inhibitors (TIMPS) have also been assessed in BAL fluid of COPD patients at stable state and at exacerbation [6]. MMP-9, TIMP-1 and TIMP-2 were significantly increased in BAL during AECOPD. Furthermore, there was significant negative correlation of MMP-9, TIMP-1 and TIMP-2 with forced expiratory volume in $1 \mathrm{~s}\left(\mathrm{FEV}_{1}\right) \%$ predicted and a significant positive correlation of TIMP-1 and TIMP-2 with residual volume \% pred in AECOPD. None of the MMPs or TIMPs correlated with diffusing capacity of the lung for carbon monoxide \% pred, indicating that they are associated with airway remodelling leading to obstruction rather than emphysema. In AECOPD the gelatinolytic activity of MMP-2 was increased and, furthermore, MMP-9 activation was significantly upregulated irrespective of lung function, bacterial or viral infections and smoking. 
In vitro studies have shown that when airway smooth muscle cells from COPD patients were exposed to cigarette smoke extract they produced higher levels of Col8a1, MMP-1, MMP-3 and MMP-10 [107].

\section{GAGs}

In the lung, GAGs support the structure of the interstitium, the subepithelial tissue and the bronchial walls and are secreted in the airway secretions. GAGs play an important role in lung function, as they regulate hydration and water homeostasis, they modulate inflammatory responses and influence lung tissue repair and remodelling [3]. Given the great structural diversity of GAGs, understanding the changes in GAG expression that occur in lung diseases may lead to novel targets for pharmacological intervention in order to prevent or treat a range of lung diseases, including COPD [36].

It has been shown that heparan sulfate is compromised in emphysema and this may lead to major disturbances in the coordination of various ECM molecules, such as growth factors and proteases, leading to impaired tissue repair and regeneration and thus to the formation of emphysematous lesions [86]. In a cohort of 97 patients with COPD, heparan sulfate and chondroitin sulfate were found to be significantly increased in the BAL of patients during exacerbations [7]. Levels of heparan sulfate were higher in BAL of patients with microbial infections. Chondroitin sulfate was found to be associated with airway remodelling, leading to obstruction rather than to emphysema. Additionally, heparan sulfate and chondroitin sulfate were significantly correlated with MMP-9, MMP-2 and MMP-12 in BAL, indicating that during AECOPD they were cleaved from their respective PGs by MMPs and subsequently washed out in BAL [7].

Hyaluronic acid metabolism has been shown to be impaired in airway smooth muscle cells from patients with COPD, as when hyaluronic acid synthesis is decreased, hyaluronic acid synthase-1 is downregulated and hyaluronidase-1 is upregulated [84]. Additionally, AECOPD have been found to be associated with increased hyaluronidase activity in BAL and subsequent degradation of hyaluronic acid (figure $3 \mathrm{~b}$ ) and this may contribute to inflammation and lung function decline during AECOPD [3].

In a recent study including 80 COPD patients in a discovery cohort and 638 COPD patients in a validation cohort, hyaluronic acid was increased during AECOPD (moderate and severe) compared with baseline and remained increased after 4 weeks [4]. Hyaluronic acid was associated with time to death and this association was independent of adjusted Charlson score, annual exacerbation rate and BODE index. Therefore, hyaluronic acid was a strong predictor for overall survival. Furthermore, serum levels of hyaluronidase-1 were higher during AECOPD (moderate and severe) but decreased after 4 weeks. Enzymatic activity of hyaluronidase-1 at stable state was inversely correlated with $\mathrm{FEV}_{1} \%$ predicted and survival time [4].

\section{Therapeutic potentials of ECM molecules in COPD}

The discovery of $\alpha_{1}$-antitrypsin deficiency (AATD) led to the hypothesis of protease-antiprotease imbalance and brought recognition to the importance of elastin fibres in maintaining the structure of the lung matrix $[108,109]$. Since then a number of attempts to influence the ECM have been performed in human and experimental animal models. In the RAPID study, a 2-year randomised, placebo-controlled trial in 180 AATD patients, it was demonstrated that weekly therapy with $\alpha_{1}$-antitrypsin reduces the loss of lung tissue and slows disease progression [101, 110,111]. The RAPID study showed for the first time that preservation of lung elastin structure may slow the progression of COPD. However, as discussed in the commentary by TURINO et al. [112], $\alpha_{1}$-antitrypsin therapy preserves elastin by specifically inhibiting neutrophil elastase; however, optimal reduction of elastin degradation would require agents also blocking other proteases that are involved in the inflammatory process, such as MMPs.

Considering the structural and functional roles of other ECM molecules, such as PGs and GAGs, that interact with collagens and elastin and control alveolar stiffness, it is tempting to hypothesise that targeting these molecules in COPD may have a therapeutic potential. In this regard, the observation that hyaluronidase enhances elastase-induced airspace enlargement led to the concept that hyaluronic acid may be used to treat emphysema [113]. A number of animal studies demonstrated that aerosolised hyaluronic acid significantly reduced elastase-induced airspace enlargement $[114,115]$. It has been suggested that hyaluronic acid acts as a barrier to agents responsible for elastolysis as it adheres to elastic fibres and protects them from enzymatic breakdown $[116,117]$. This is a naturally occurring process since hyaluronic acid has a close anatomic association with elastic fibres [118]. It was also shown that delayed administration of hyaluronic acid aerosol to tobacco smoke-exposed mice, 1 month after the tobacco smoke injury, was still effective in decreasing the progression of tobacco smoke-induced emphysema [119].

In a more recent small study, eight COPD patients received hyaluronic acid $0.01 \%$ twice daily for 14 days and three patients received placebo [120]. The study showed that administration of aerosolised hyaluronic 
acid is safe and that levels of desmosine and isodesmosine, biomarkers of elastin degradation, were significantly reduced over baseline levels in the group that received hyaluronic acid [120].

\section{Conclusions and future steps}

Various studies have shown that ECM turnover products can be used as serum biomarkers for disease severity in patients with COPD (table 1) [2,5]. Recently, hyaluronic acid and its degrading enzyme hyaluronidase- 1 have been shown to be very promising as potential targets to control inflammation and remodelling in the airways of COPD patients [4].

The only effective treatment for lung diseases at end-stage is lung transplantation. However, due to the limited amount of available donor lungs and the subsequent immunosuppression this clinical application is limited [27]. Recently, the use of lung progenitor cells for lung regeneration after injury has shown exciting results [121]. There is now evidence that the repair of injured and diseased lungs can be performed by the application of cells that hold regenerative capacity, such as bone marrow stem cells, embryonic stem cells and inducible pluripotent stem cells [121]. Today, with the aid of novel tissue engineering techniques, even the regeneration of whole lung can be achieved in the lab using stem cells and de-cellularised tissue scaffolds. As ECM has a great influence on the morphology of cells [122], as well as on cell spreading, motility and viability [123], such bioartificial and biocompatible de-cellularised ECM scaffolds that have similar biomechanical properties as lung tissue show a great potential for stem cell-based regenerative therapies. In this respect, mesenchymal stromal cells (MSCs) grown on biodegradable and biosynthetic scaffolds have been used to develop tissue engineered tracheas in animal models of tracheal defects and human clinical trials $[124,125]$. Such an application has already been tested in a female patient suffering airway damage from tuberculosis [126]. In this case, MSC-derived chondrocytes were cultured on an acellular tracheal scaffold to form a functional human airway, which was subsequently transplanted into the patient. Attempts for whole-lung tissue engineering have been made in animal models [127-130]. In these attempts, the use of whole-lung de-cellularisation strategies followed by reseeding the de-cellularised lung scaffold with primary airway epithelial cells, vascular endothelial cells [127, 128], whole-lung cell suspension digests [127], MSCs [131, 132], or differentiated pluripotent embryonic stem cells, or inducible pluripotent stem cells has been evaluated. Culture of organs took place in bioreactors and, subsequently, the organs were re-implanted and demonstrated efficient gas exchange $[127,128,133]$. Such attempts have been applied to pigs, nonhuman primates and human lungs $[128,133,134]$. Future efforts are needed to determine whether functional and transplantable organs may be generated on synthetic scaffolds after recellularisation with autologous progenitor or stem cells [27].

Disentangling the complete molecular structure of the lung ECM in health and disease would be an important step to identify novel biomarkers for the progression and therapy of lung diseases [27]. Developing new methods for the analysis of the lung ECM of the lungs will likely help us understand the role of ECM in tissue pathophysiology [27]. For this, it is essential to understand the complex interactions between lung cells and the core matrisome $[135,136]$.

Conflict of interest: None declared.

\section{References}

1 Dunsmore SE. Treatment of COPD: a matrix perspective. Int J Chron Obstruct Pulmon Dis 2008; 3: $113-122$.

2 Stolz D, Leeming DJ, Kristensen JHE, et al. Systemic biomarkers of collagen and elastin turnover are associated with clinically relevant outcomes in COPD. Chest 2017; 151: 47-59.

3 Papakonstantinou E, Roth M, Klagas I, et al. COPD exacerbations are associated with proinflammatory degradation of hyaluronic acid. Chest 2015; 148: 1497-1507.

4 Papakonstantinou E, Bonovolias I, Roth M, et al. Serum levels of hyaluronic acid are associated with COPD severity and predict survival. Eur Respir J 2019; 53: 1801183.

5 Schumann DM, Leeming D, Papakonstantinou E, et al. Collagen degradation and formation are elevated in exacerbated COPD compared with stable disease. Chest 2018; 154: 798-807.

6 Papakonstantinou E, Karakiulakis G, Batzios S, et al. Acute exacerbations of COPD are associated with significant activation of matrix metalloproteinase 9 irrespectively of airway obstruction, emphysema and infection. Respir Res 2015; 16: 78.

7 Papakonstantinou E, Klagas I, Roth M, et al. Acute exacerbations of COPD are associated with increased expression of heparan sulfate and chondroitin sulfate in BAL. Chest 2016; 149: 685-695.

8 Eyre DR, Muir H. Type III collagen: a major constituent of rheumatoid and normal human synovial membrane. Connect Tissue Res 1975; 4: 11-16.

9 Genovese F, Manresa AA, Leeming DJ, et al. The extracellular matrix in the kidney: a source of novel non-invasive biomarkers of kidney fibrosis? Fibrogenesis Tissue Repair 2014; 7: 4.

10 Karsdal MA, Krarup H, Sand JM, et al. Review article: the efficacy of biomarkers in chronic fibroproliferative diseases - early diagnosis and prognosis, with liver fibrosis as an exemplar. Aliment Pharmacol Ther 2014; 40: 233-249.

11 Karsdal MA, Manon-Jensen T, Genovese F, et al. Novel insights into the function and dynamics of extracellular matrix in liver fibrosis. Am J Physiol Gastrointest Liver Physiol 2015; 308: G807-G830. 
Veidal SS, Karsdal MA, Vassiliadis E, et al. MMP mediated degradation of type VI collagen is highly associated with liver fibrosis - identification and validation of a novel biochemical marker assay. PLoS One 2011; 6: e24753. Suki B, Ito S, Stamenovic D, et al. Biomechanics of the lung parenchyma: critical roles of collagen and mechanical forces. J Appl Physiol 2005; 98: 1892-1899.

Negrini D, Passi A, De Luca G, et al. Matrix proteoglycans in development of pulmonary edema. In: Garg HG, Roughley PJ, Hales CA, eds. Proteoglycans In Lung Disease. New York, Marcel Dekker, 2000; pp. 143-168

Wight TN, Frevert CW, Debley JS, et al. Interplay of extracellular matrix and leukocytes in lung inflammation. Cell Immunol 2017; 312: 1-14.

Sorokin L. The impact of the extracellular matrix on inflammation. Nat Rev Immunol 2010; 10: 712-723.

Suki B, Bates JH. Extracellular matrix mechanics in lung parenchymal diseases. Respir Physiol Neurobiol 2008; 163: 33-43.

Faffe DS, Zin WA. Lung parenchymal mechanics in health and disease. Physiol Rev 2009; 89: 759-775.

Frantz C, Stewart KM, Weaver VM. The extracellular matrix at a glance. J Cell Sci 2010; 123: 4195-4200.

Bosman FT, Stamenkovic I. Functional structure and composition of the extracellular matrix. J Pathol 2003; 200: 423-428.

Liesker JJ, Ten Hacken NH, Zeinstra-Smith M, et al. Reticular basement membrane in asthma and COPD similar thickness, yet different composition. Int J Chron Obstruct Pulmon Dis 2009; 4: 127-135.

Menter DG, Dubois RN. Prostaglandins in cancer cell adhesion, migration, and invasion. Int J Cell Biol 2012; 2012: 723419.

Wagenseil JE, Mecham RP. New insights into elastic fiber assembly. Birth Defects Res C Embryo Today 2007; 81 229-240.

Sakai LY, Keene DR, Glanville RW, et al. Purification and partial characterization of fibrillin, a cysteine-rich structural component of connective tissue microfibrils. J Biol Chem 1991; 266: 14763-14770.

Kristensen JH, Karsdal MA, Sand JM, et al. Serological assessment of neutrophil elastase activity on elastin during lung ECM remodeling. BMC Pulm Med 2015; 15: 53.

Kristensen JH, Larsen L, Dasgupta B, et al. Levels of circulating MMP-7 degraded elastin are elevated in pulmonary disorders. Clin Biochem 2015; 48: 1083-1088.

Burgstaller G, Oehrle B, Gerckens M, et al. The instructive extracellular matrix of the lung: basic composition and alterations in chronic lung disease. Eur Respir J 2017; 50: 1601805.

Ito S, Ingenito EP, Brewer KK, et al. Mechanics, nonlinearity, and failure strength of lung tissue in a mouse model of emphysema: possible role of collagen remodeling. J Appl Physiol 2005; 98: 503-511.

Pacini A, Gardi C, Corradeschi F, et al. In vivo stimulation of lung collagen synthesis by collagen derived peptides. Res Commun Chem Pathol Pharmacol 1990; 68: 89-101.

Finlay GA, O'Donnell MD, O'Connor CM, et al. Elastin and collagen remodeling in emphysema. A scanning electron microscopy study. Am J Pathol 1996; 149: 1405-1415.

Dunsmore SE, Rannels DE. Extracellular matrix biology in the lung. Am J Physiol 1996; 270: L3-L27.

FASEB J 1992; 6: 2639-2645

Johnson Z, Proudfoot AE, Handel TM. Interaction of chemokines and glycosaminoglycans: a new twist in the regulation of chemokine function with opportunities for therapeutic intervention. Cytokine Growth Factor Rev 2005; 16: 625-636.

Turino GM, Cantor JO. Hyaluronan in respiratory injury and repair. Am J Respir Crit Care Med 2003; 167; 1169-1175.

Gerdin B, Hallgren R. Dynamic role of hyaluronan (HYA) in connective tissue activation and inflammation. J Intern Med 1997; 242: 49-55.

Papakonstantinou E, Karakiulakis G. The "sweet" and "bitter" involvement of glycosaminoglycans in lung diseases: pharmacotherapeutic relevance. Br J Pharmacol 2009; 157: 1111-1127.

Stern R, Asari AA, Sugahara KN. Hyaluronan fragments: an information-rich system. Eur J Cell Biol 2006; 85: 699-715.

Lennon FE, Singleton PA. Role of hyaluronan and hyaluronan-binding proteins in lung pathobiology. Am J Physiol Lung Cell Mol Physiol 2011; 301: L137-L147.

Itano N, Sawai T, Yoshida M, et al. Three isoforms of mammalian hyaluronan synthases have distinct enzymatic properties. J Biol Chem 1999; 274: 25085-25092.

Papakonstantinou E, Kouri FM, Karakiulakis G, et al. Increased hyaluronic acid content in idiopathic pulmonary arterial hypertension. Eur Respir J 2008; 32: 1504-1512.

Lipscombe RJ, Nakhoul AM, Sanderson CJ, et al. Interleukin-5 binds to heparin/heparan sulfate. A model for an interaction with extracellular matrix. J Leukoc Biol 1998; 63: 342-350.

Aruffo A, Stamenkovic I, Melnick M, et al. CD44 is the principal cell surface receptor for hyaluronate. Cell 1990; 61: 1303-1313.

Teder P, Vandivier RW, Jiang D, et al. Resolution of lung inflammation by CD44. Science 2002; 296: 155-158. alveolar macrophages. The role of HA size and CD44. J Clin Invest 1996; 98: 2403-2413.

Mascarenhas MM, Day RM, Ochoa CD, et al. Low molecular weight hyaluronan from stretched lung enhances interleukin-8 expression. Am J Respir Cell Mol Biol 2004; 30: 51-60.

Mummery RS, Rider CC. Characterization of the heparin binding properties of IL-6. J Immunol 2000; 165: 5671-5679.

Menart V, Fonda I, Kenig M, et al. Increased in vitro cytotoxicity of TNF-alpha analog LK-805 is based on the interaction with cell surface heparan sulfate proteoglycan. Ann N Y Acad Sci 2002; 973: 194-206.

Whitelock JM, Iozzo RV. Heparan sulfate: a complex polymer charged with biological activity. Chem Rev 2005; 105: 2745-2764.

Poole AR. Proteoglycans in health and disease: structures and functions. Biochem J 1986; 236: 1-14.

Iida J, Wilhelmson KL, Ng J, et al. Cell surface chondroitin sulfate glycosaminoglycan in melanoma: role in the activation of pro-MMP-2 (pro-gelatinase A). Biochem J 2007; 403: 553-563. 
51 Rodriguez E, Roland SK, Plaas A, et al. The glycosaminoglycan attachment regions of human aggrecan. J Biol Chem 2006; 28127: 18444-18450.

52 Miwa HE, Gerken TA, Huynh TD, et al. Mammalian expression of full-length bovine aggrecan and link protein: formation of recombinant proteoglycan aggregates and analysis of proteolytic cleavage by ADAMTS-4 and MMP-13. Biochim Biophys Acta 2006; 1760: 472-486.

53 Somerville RP, Longpre JM, Apel ED, et al. ADAMTS7B, the full-length product of the ADAMTS7 gene, is a chondroitin sulfate proteoglycan containing a mucin domain. J Biol Chem 2004; 279: 35159-35175.

54 Shannon JM, McCormick-Shannon K, Burhans MS, et al. Chondroitin sulfate proteoglycans are required for lung growth and morphogenesis in vitro. Am J Physiol Lung Cell Mol Physiol 2003; 285: L1323-L1336.

55 Zhang Z, Miao L, Wang L. Inflammation amplification by Versican: the first mediator. Int J Mol Sci 2012; 13: 6873-6882.

56 Kim S, Takahashi H, Lin WW, et al. Carcinoma-produced factors activate myeloid cells through TLR2 to stimulate metastasis. Nature 2009; 457: 102-106.

57 Wang W, Xu GL, Jia WD, et al. Ligation of TLR2 by Versican: a link between inflammation and metastasis. Arch Med Res 2009; 40: 321-323.

58 Srinoulprasert Y, Kongtawelert P, Chaiyaroj SC. Chondroitin sulfate B and heparin mediate adhesion of Penicillium marneffei conidia to host extracellular matrices. Microb Pathog 2006; 40: 126-132.

59 Penc SF, Pomahac B, Eriksson E, et al. Dermatan sulfate activates nuclear factor-kappa b and induces endothelial and circulating intercellular adhesion molecule-1. J Clin Invest 1999; 103: 1329-1335.

60 Tonnaer EL, Hafmans TG, Van Kuppevelt TH, et al. Involvement of glycosaminoglycans in the attachment of pneumococci to nasopharyngeal epithelial cells. Microbes Infect 2006; 8: 316-322.

61 Kinsella MG, Bressler SL, Wight TN. The regulated synthesis of versican, decorin, and biglycan: extracellular matrix proteoglycans that influence cellular phenotype. Crit Rev Eukaryot Gene Expr 2004; 14: 203-234.

62 Sugahara K, Mikami T, Uyama T, et al. Recent advances in the structural biology of chondroitin sulfate and dermatan sulfate. Curr Opin Struct Biol 2003; 13: 612-620.

63 Villena J, Brandan E. Dermatan sulfate exerts an enhanced growth factor response on skeletal muscle satellite cell proliferation and migration. J Cell Physiol 2004; 198: 169-178.

64 Monzon ME, Casalino-Matsuda SM, Forteza RM. Identification of glycosaminoglycans in human airway secretions. Am J Respir Cell Mol Biol 2006; 34: 135-141.

65 Praus R, Brettschneider I. Glycosaminoglycans in embryonic and postnatal human cornea. Ophthal Res 1975; 7: 452-458.

66 Brown GM, Huckerby TN, Bayliss MT, et al. Human aggrecan keratan sulfate undergoes structural changes during adolescent development. J Biol Chem 1998; 273: 26408-26414.

67 Postma DS, Timens W. Remodeling in asthma and chronic obstructive pulmonary disease. Proc Am Thorac Soc 2006; 3: 434-439.

68 Saetta M, Turato G, Maestrelli P, et al. Cellular and structural bases of chronic obstructive pulmonary disease. Am J Respir Crit Care Med 2001; 163: 1304-1309.

69 Ito JT, Lourenço JD, Righetti RF, et al. Extracellular matrix component remodeling in respiratory diseases: what has been found in clinical and experimental studies? Cells 2019; 8: 342.

70 Brusselle GG, Joos GF, Bracke KR. New insights into the immunology of chronic obstructive pulmonary disease. Lancet 2011; 378: 1015-1026.

71 Higham A, Quinn AM, Cancado JED, et al. The pathology of small airways disease in COPD: Historical aspects and future directions. Respir Res 2019; 20: 49.

72 Hogg JC, Timens W. The pathology of chronic obstructive pulmonary disease. Annu Rev Pathol 2009; 4: 435-459.

73 Abraham T, Hogg J. Extracellular matrix remodeling of lung alveolar walls in three dimensional space identified using second harmonic generation and multiphoton excitation fluorescence. J Struct Biol 2010; 171: 189-196.

74 Shifren A, Durmowicz AG, Knutsen RH, et al. Elastin protein levels are a vital modifier affecting normal lung development and susceptibility to emphysema. Am J Physiol Lung Cell Mol Physiol 2007; 292: L778-L787.

75 Kononov S, Brewer K, Sakai H, et al. Roles of mechanical forces and collagen failure in the development of elastase-induced emphysema. Am J Respir Crit Care Med 2001; 164: 1920-1926.

76 Vlahovic G, Russell ML, Mercer RR, et al. Cellular and connective tissue changes in alveolar septal walls in emphysema. Am J Respir Crit Care Med 1999; 160: 2086-2092.

77 Anciaes AM, Olivo CR, Prado CM, et al. Respiratory mechanics do not always mirror pulmonary histological changes in emphysema. Clinics 2011; 66: 1797-1803.

78 Seemungal TA, Donaldson GC, Paul EA, et al. Effect of exacerbation on quality of life in patients with chronic obstructive pulmonary disease. Am J Respir Crit Care Med 1998; 157: 1418-1422.

79 Mecham RP. Elastin in lung development and disease pathogenesis. Matrix Biol 2018; 73: 6-20.

80 Gooptu B, Ekeowa UI, Lomas DA. Mechanisms of emphysema in $\alpha 1$-antitrypsin deficiency: molecular and cellular insights. Eur Respir J 2009; 34: 475-488.

81 Leeming DJ, Sand JM, Nielsen MJ, et al. Serological investigation of the collagen degradation profile of patients with chronic obstructive pulmonary disease or idiopathic pulmonary fibrosis. Biomark Insights 2012; 7: $119-126$.

82 Sand JM, Martinez G, Midjord AK, et al. Characterization of serological neo-epitope biomarkers reflecting collagen remodeling in clinically stable chronic obstructive pulmonary disease. Clin Biochem 2016; 49: $1144-1151$.

83 Sand JM, Leeming DJ, Byrjalsen I, et al. High levels of biomarkers of collagen remodeling are associated with increased mortality in COPD - results from the ECLIPSE study. Respir Res 2016; 17: 125.

84 Klagas I, Goulet S, Karakiulakis G, et al. Decreased hyaluronan in airway smooth muscle cells from patients with asthma and COPD. Eur Respir J 2009; 34: 616-628.

85 Haeger S, Haeger SM, Yang Y, et al. Heparan sulfate in the developing, healthy and Injured lung. Am J Respir Cell Mol Biol 2016; 55: 5-11.

86 Smits NC, Shworak NW, Dekhuijzen PN, et al. Heparan sulfates in the lung: structure, diversity, and role in pulmonary emphysema. Anat Rec (Hoboken) 2010; 293: 955-967. 
Thompson HL, Schulman ES, Metcalfe DD. Identificatiomn of chondroitin sulfate E in human mast cells. J Immunol 1988; 40: 2708-2713.

88 Caterson B, Melrose J. Keratan sulfate, a complex glycosaminoglycan with unique functional capability. Glycobiology 2018; 4: 182-206.

89 Barnes PJ. Mediators of chronic obstructive pulmonary disease. Pharmacol Rev 2004; 56: 515-548.

90 Rabinovitch M. Pathobiology of pulmonary hypertension. Extracellular matrix. Clin Chest Med 2001; 22: 433-449.

91 Noble PW, Jiang D. Matrix regulation of lung injury inflammation and repair: the role of innate immunity. Proc Am Thor Soc 2006; 3: 401-404.

92 Laurent GJ, Chambers RC, Hill MR, et al. Regulation of matrix turnover: fibroblasts, forces, factors and fibrosis. Biochem Soc Trans 2007; 35: 647-651.

93 McAnulty RJ, Laurent GJ. Collagen synthesis and degradation in vivo. Evidence for rapid rates of collagen turnover with extensive degradation of newly synthesized collagen in tissues of the adult rat. Coll Rel Res 1987; 7: 93-104.

94 Lourenco JD, Ito JT, Cervilha DAB, et al. The tick-derived rBmTI-A protease inhibitor attenuates the histological and functional changes induced by cigarette smoke exposure. Histol Histopathol 2018; 33: 289-298.

95 Lourenco JD, Neves LP, Olivo CR, et al. A treatment with a protease inhibitor recombinant from the cattle tick (Rhipicephalus Boophilus microplus) ameliorates emphysema in mice. PLoS One 2014; 9: e98216.

96 Rodrigues R, Olivo CR, Lourenco JD, et al. Amurine model of elastase- and cigarette smoke-induced emphysema. J Bras Pneumol 2017; 43: 95-100.

97 Gomes RF, Shen X, Ramchandani R, et al. Comparative respiratory system mechanics in rodents. J Appl Physiol 2000; 89: 908-916.

98 Vestbo J, Anderson W, Coxson HO, et al. Evaluation of COPD Longitudinally to Identify Predictive Surrogate End-points (ECLIPSE). Eur Respir J 2008; 31: 869-873.

99 Dickens JA, Miller BE, Edwards LD, et al. COPD association and repeatability of blood biomarkers in the ECLIPSE cohort. Respir Res 2011; 12: 146.

100 Singh D, Edwards L, Tal-Singer R, et al. Sputum neutrophils as a biomarker in COPD: findings from the ECLIPSE study. Respir Res 2010; 11: 77.

101 Aaron SD, Vandemheen KL, Ramsay T, et al. Multi-analyte profiling and variability of inflammatory markers in blood and induced sputum in patients with stable COPD. Respir Res 2010; 11: 41.

102 Chapman KR, Burdon JGW, Piitulainen E, et al. Intravenous augmentation treatment and lung density in severe alpha-1 antitrypsin deficiency (RAPID): a randomized double-blinded, placebo-controlled trial. Lancet 2015; 386: 360-368.

103 Barascuk N, Veidal SS, Larsen L, et al. A novel assay for extracellular matrix remodeling associated with liver fibrosis: An enzyme-linked immunosorbent assay (ELISA) for a MMP-9 proteolytically revealed neo-epitope of type III collagen. Clin Biochem 2010; 43: 899-904.

104 Leeming D, He Y, Veidal S, et al. A novel marker for assessment of liver matrix remodeling: an enzyme-linked immunosorbent assay (ELISA) detecting a MMP generated type I collagen neo-epitope (C1M). Biomarkers 2011; 16: 616-628.

105 Sand JM, Knox AJ, Lange P, et al. Accelerated extracellular matrix turnover during exacerbations of COPD. Respir Res 2015; 16: 69.

106 Annoni R, Lanças T, Yukimatsu Tanigawa R, et al. Extracellular matrix composition in COPD. Eur Respir J 2012; 40: $1362-1373$

107 Papakonstantinou E, Bonovolias I, Roth M, et al. Hyaluronic acid, heparan sulfate and chondroitin sulfate are altered during exacerbations of COPD. Eur Respir J 2017; 50: PA994.

108 Chen L, Ge Q, Tjin G, et al. Effects of cigarette smoke extract on human airway smooth muscle cells in COPD. Eur Respir J 2014; 44: 634-646.

109 Laurell C-B, Eriksson S. The electrophoretic alpha-1 globulin pattern of serum in alpha-1 antitrypsin deficiency (AATD). Scand J Clin Lab Invest 1963; 15: 132-140.

110 Sandberg LB, Soske NT, Leslie JG. Elastin structure, biosynthesis and relation to disease states. N Eng J Med 1981; 304: 566-579.

111 McElvaney NG, Burdon J, Holmes M, et al. Long-term efficacy and safety of $\alpha 1$ proteinase inhibitor treatment for emphysema caused by severe $\alpha 1$ antitrypsin deficiency: an open-label extension trial (RAPID-OLE). Lancet Respir Med 2017; 5: 51-60.

112 Turino GM, Ma S, Lin YY, et al. The therapeutic potential of hyaluronan in COPD. Chest 2018; 153: 792-798.

113 Cantor JO, Cerreta JM, Armand G, et al. Pulmonary air-space enlargement induced by intratracheal instillment of hyaluronidase and concomitant exposure to 60\% oxygen. Exp Lung Res 1993; 19: 177-192.

114 Cantor J, Turino GM. Modulation of air-space enlargement in elastase-induced emphysema by intratracheal instillment of hyaluronidase and hyaluronic acid. Exp Lung Res 1995; 21: 423-436.

115 Cantor JO, Cerreta JN, Armand G, et al. Further investigation of the use of intratracheally administered hyaluronic acid to ameliorate elastase-induced emphysema. Exp Lung Res 1997; 23: 229-244.

116 Cantor JO, Cerreta Joseph M, Armand G, et al. Aerosolized hyaluronic acid decreases alveolar injury induced by human neutrophil elastase. Proc Soc Exp Biol Med 1998; 217: 471-475.

117 Cantor JO, Shteyngart B, Cerreta JM, et al. The effect of hyaluronan on elastic fiber injury in vitro and elastase-induced airspace enlargement in vivo. Proc Soc Exp Biol Med 2000; 225: 65-71.

118 Baccarani-Contri M, Vincenzi D, Cicchetti F, et al. Immunocytochemical localization of proteoglycans within normal elastin fibers. Eur J Cell Biol 1990; 53: 305-312.

119 Cantor JO, Cerreta JM, Ochoa M, et al. Therapeutic effect of hyaluronan on smoke-induced elastin fiber injury: does delayed treatment affect efficacy? Lung 2011; 189: 51-56.

120 Cantor J, Ma S, Turino G. A pilot clinical trial to determine the safety and efficacy of aerosolized hyaluronan as a treatment for COPD. Int J Chron Obstruct Pulmon Dis 2017; 12: 2747-2752.

121 Akram KM, Patel N, Spiteri MA, et al. Lung regeneration: endogenous and exogenous stem cell mediated therapeutic approaches. Int J Mol Sci 2016; 17: 128. 

One 2013; 8: e63121.

123 Naba A, Clauser KR, Hoersch S, et al. The matrisome: in silico definition and in vivo characterization by proteomics of normal and tumor extracellular matrices. Mol Cell Proteomics 2012; 11: M111.014647.

124 Omori K, Tada Y, Suzuki T, et al. Clinical application of in situ tissue engineering using a scaffolding technique for reconstruction of the larynx and trachea. Ann Otol Rhinol Laryngol 2008; 117: 673-678.

125 Omori K, Nakamura T, Kanemaru S, et al. In situ tissue engineering of the cricoid and trachea in a canine model. Ann Otol Rhinol Laryngol 2008; 117: 609-613.

126 Macchiarini P, Jungebluth P, Go T, et al. Clinical transplantation of a tissue-engineered airway. Lancet 2008; 372: 2023-2030.

127 Ott HC, Clippinger B, Conrad C, et al. Regeneration and orthotopic transplantation of a bioartificial lung. Nat Med 2010; 16: 927-933.

128 Petersen TH, Calle EA, Zhao L, et al. Tissue-engineered lungs for in vivo implantation. Science 2010; 329: $538-541$.

129 Cortiella J, Niles J, Cantu A, et al. Influence of acellular natural lung matrix on murine embryonic stem cell differentiation and tissue formation. Tissue Eng Part A 2010; 16: 2565-2580.

130 Ghaedi M, Calle EA, Mendez JJ, et al. Human IPS cell-derived alveolar epithelium repopulates lung extracellular matrix. J Clin Invest 2013; 123: 4950-4962.

131 Daly AB, Wallis JM, Borg ZD, et al. Initial binding and recellularization of decellularized mouse lung scaffolds with bone marrow-derived mesenchymal stromal cells. Tissue Eng Part A 2012; 18: 1-16.

132 Wallis JM, Borg ZD, Daly AB, et al. Comparative assessment of detergent-based protocols for mouse lung de-cellularization and re-cellularization. Tissue Eng Part C Methods 2012; 18: 420-432.

133 Bonvillain RW, Scarritt ME, Pashos NC, et al. Nonhuman primate lung decellularization and recellularization using a specialized large-organ bioreactor. J Vis Exp 2013; 15: e50825.

134 Booth AJ, Hadley R, Cornett AM, et al. Acellular normal and fibrotic human lung matrices as a culture system for in vitro investigation. Am J Respir Crit Care Med 2012; 186: 866-876.

135 Burgess JK, Mauad T, Tjin G, et al. The extracellular matrix - the under-recognized element in lung disease? J Pathol 2016; 240: 397-409.

136 White ES. Lung extracellular matrix and fibroblast function. Ann Am Thorac Soc 2015; 12: Suppl. 1, S30-S33. 